\title{
The Kenyan Education Curriculum: From Development to Sustainability
}

\author{
Grace A. Koteng \\ Kisii University, Kisumu Campus, Kisumu, Kenya
}

\begin{abstract}
Education for sustainable development (ESD) translates to acquisition of knowledge and skills to support growth. Sustainability adds value to the acquired learning in education; and this, then translates to the growth and development of the individual, the community, and country at large. Curriculum should therefore be designed and implemented in ways that link teaching and learning to sustainable development. A survey conducted established that products of the Kenya curriculum have exhibited gaps in this aspect. A random survey and interviews targeting 20 of each of the various stakeholders including secondary school teachers, university lecturers, and secondary school and university graduates, were conducted. During the survey, factors considered included the goals of the curriculum offered, its implementation, and relations with sustainable development. Gaps were identified and the way forward suggested. The study was conducted in Western Kenya. The results were analysed by percentage, and conclusions drawn. Recommendations were suggested from the conclusions.
\end{abstract}

Keywords: education, knowledge, skills, sustainability, development

\section{Introduction and History of Education and Sustainability}

Education is the process of imparting and acquiring knowledge and skills that enables one to reason, judge, and apply the knowledge and skills towards self-development in particular, and community and national development at large (Koteng', 2009). Bossel (1999) considered sustainability as a dynamic process that encompasses change in societies and their environment; and it allows continuous, viable, and vigorous development which translates to sustainable development. Winograd and Farrow (1995) viewed sustainability as essentially a process of change that allows current human needs to be satisfied without compromising the possibilities of future generations.

Education for sustainable development (ESD), therefore, is the facilitation of knowledge and skills towards strengthening the growth of a nation. Towards this, educational goals, teaching and learning objectives, and evaluation of teaching and learning ought to be considered in tandem. This is more so since educational goals are statements on the outcomes of education; the objectives are the implementation; and evaluation is the assessment of the implementation of the goals, and the curriculum as a whole. Curriculum is, therefore, the sum total of experiences learners undergo.

ESD was first endorsed at the United Nations General Assembly in 1987. Initial thoughts concerning ESD were captured in Chapter 36 of Agenda 21 "Promoting Education, Public Awareness, and Training." This chapter identified four major areas to begin the work of ESD, namely: (a) improvement of basic education; (b)

Grace A. Koteng, senior lecturer, Department of Education, Kisii University, Kisumu Campus. 
reorientation of existing education to address sustainable development; (c) development of public understanding and awareness of the goals of sustainable society; and (d) training.

In the first major area of improving basic education, pupils learn to read, write, and figure accounts; and develop skills necessary to fulfil their expected roles in their households and community; how their government functions, and about the world beyond their community. In this way, simply increasing basic literacy will advance sustainable development. To achieve this, basic education ought to address sustainability, and expanded to include critical thinking skills, skills to interpret information, to formulate questions, and the ability to analyse issues that confront communities. This is the core value of ESD that sets it apart from other educational efforts. Over the years, since its adoption, students' enrolment has increased, and the gender gap is narrowing, but not closed yet.

The second major area, to reorient existing education to address sustainable development, refers to understanding the changes required for ESD. An appropriately reoriented basic education includes more principles, skills, perspectives, and values related to sustainability than are currently included in most education systems. Hence, it is about quantity, appropriateness, and relevance. Reorienting education also requires teaching and learning knowledge, skills, perspectives, and values that will guide and motivate people to pursue sustainable livelihoods, to participate in a democratic society, and to live in a sustainable manner. This reorientation to address sustainability is something that should occur throughout the formal education system from primary, through secondary, middle level colleges, and universities.

The third major area, namely, to develop public understanding and awareness of the goals of a sustainable society, enables the society to obtain the knowledge and skills required to contribute towards these goals.

Lastly, but not least, the fourth major area, training, is distinct from education in that it is specific to a particular job or class of jobs. Training teaches workers how to use equipment safely, be more efficient, and comply with regulations. Training informs people of accepted practices and procedures and gives them skills to perform specific tasks. In contrast, education is a socially transforming process that gives people knowledge, skills, perspectives, and values through which they can participate and contribute to their own community and nation

Further, the chapter recommended that since ESD is a lifelong process, the formal, non-formal, and informal educational sectors should work together to accomplish local sustainability goals.

In accordance with the fore-going, and in order to achieve sustainability, the government of Kenya has set up specific national goals in education, from which the instructional objectives are derived.

\section{Kenya's National Goals of Education}

Gagne and Briggs (1979) referred to educational goals as statements of the outcomes of education. Educational goals are activities made possible by learning which is brought about by deliberately planned instruction. In Kenya, these are eight broad statements formulated and pronounced at the national level that constitute the national goals of education in Kenya. According to the Ministry of Education, Science, and Technology (MOEST) (2003), education in Kenya targets to achieve the following:

1. Foster nationalism and patriotism, and promote national unity: This will work towards helping the youth acquire a sense of nationhood and be able to live and interact as Kenyans despite the ethnic, race, and religious differences. In the process, they will learn the sense of nationhood, promote positive attitudes of mutual respect, foster patriotism, and make positive contribution to the life of the nation. 
2. Promote socio-economic, technological, and industrial needs for national development: Education should prepare the youth of the country to play an effective and productive role in the life of the nation, covering social, economic, technical, and industrial needs:

Under socio-economic needs, education in Kenya must prepare children for the changes in attitudes and relationships, which are necessary for the smooth progress of a rapidly developing economy. Education should assist the youth to adapt to the change that comes with rapid development.

Under technical and industrial skill, education in Kenya should provide the learners with the necessary skills and attitudes for industrial development, and the changing global trends.

3. Promote individual development and self-fulfilment by providing opportunities for the fullest development of individual talents and personality. It should assist children to develop their potential, interests, and abilities. A vital aspect of individual development is character building.

4. Promote sound moral and religious values: Education should provide for the development of knowledge, skills, and attitudes that will enhance acquisition of sound moral values and help children grow up into self-disciplined, self-reliant, and integrated citizens.

5. Promote social equality and responsibility: In order to provide a sense of social responsibility within an education system which provides equal educational opportunities for all. It should give all children varied and challenging opportunities for collective and corporate social services irrespective of gender, ability, or geographical environment.

6. Promote respect for and development of Kenya's rich and varied cultures: In order to instil in youth of Kenya an understanding of past and present cultures and their valid place in contemporary society. Thus, they will be able to blend the best of traditional values with the changed requirements that follow rapid development in order to build a stable and modem society.

7. Promote international consciousness and foster positive attitudes towards other nations: As part of the international community, Kenya is a part of the complicated and interdependent network of peoples and nations. Education should therefore lead the youth of the country to accept membership in this international community with all the obligations, responsibilities, rights, and benefits that this membership entails.

8. Promote positive attitudes towards good health and environmental protection: Education should inculcate in the youth the value of good health in order to avoid indulging in activities that will lead to physical or mental ill health. It should foster positive attitudes towards environmental development and conservation. It should lead the youth to appreciate the need for a healthy environment.

The preceding statements, constituted in the Kenyan educational goals, are rather broad, and are made at the national level. From these broad statements, however, is designed a curriculum in terms of courses and subjects to be taught at the different levels of the education system. For each level and course/subject, in the curriculum, other goals are stated. These ones are narrower in scope, hence, more specific than the eight above. They describe behaviours which can be achieved in shorter periods of time. They make a good starting point for the classroom teacher who, at this stage, derives the instructional objectives from the goals.

During the implementation of the national goals, education ought to lead to development in the production of skilled manpower; increase in individual's productivity; reduction in social and economic inequality; promotion of economic growth; and addressing emerging challenges. In Kenya, while in the process of achieving the above outlines, and the millennium development goals (MDGs), the definition of development rested in the increase in the number of institutions and learners. Additionally, the development incorporated 
sustaining free primary education (FPE); free day secondary education; promotion of gender equity in education; expansion of school infrastructure; and right of access to education. According to records in MOEST, all this led to a significant growth in both the number of educational institutions and student enrolment:

1. With FPE introduced in 2003, enrolment rose from 7,394,800 in 2004 to 10,293,200 in 2013;

2. Secondary school enrolment rose from 926,100 in 2004 to 2,103,700 in 2013;

3. Enrolment of technical vocational education training (TVET) institutions increased from 85,200 in 2008 to 127,691 in 2012.

MOEST records also indicate that in order to accommodate the growing number of learners, the number of institutions also increased as shown, from 2009 to 2013:

1. Pre-primary schools: from 38,247 to 40,145 ;

2. Primary schools: from 26,667 to 30,122 ;

3. Secondary schools: from 6,971 to 8,848 ;

4. Pre-primary teacher training colleges: from 105 to 123 ;

5. Youth polytechnics: from 579 to 701 ;

6. Technical training institutes: from 19 to 35 ;

7. National polytechnics: from 2 to 3 ;

8. The number of public and private universities, and university colleges rose from 31 in 2009 to 68 in 2014.

All this lay in tandem with the achievement of the MDGs little or no consideration for sustainable development.

\section{Evaluation of Teaching and Learning}

Following this unprecedented development in line with the MDGs, a survey was conducted in July to August, 2015, to explore stakeholders' perception on the sustainability of the Kenyan education curriculum. Participants in the survey were stakeholders, including parents, students who had completed several levels of studies, employers, and teachers (including school heads). During the assessment, both qualitative and quantitative evaluation was conducted to test the effectiveness of teaching and learning. At the evaluation several factors were considered: (a) completion of syllabus; (b) gaps, if any, between curriculum design, implementation, and evaluation; (c) availability of enough resources; and (d) accreditation of courses taught. Data were collected using interviews; and the interviewees were implementers, products, supporters, and consummers of the curriculum. From the results obtained, review of the curriculum was proposed, gaps to be filled identified, and suggestions for updates provided.

While conducting the survey, it was noted that opinion from teachers, who are the implementers of the curriculum, indicate that despite the development of good national goals of education, the implementation is not in tandem. Teachers care more about the performance of their students during the national examinations, concentrating on how to excel and score the highest grades possible. They rush to complete the syllabus, concentrating on the examinable areas and omitting the non-examinable areas which are also required to be taught in order to achieve the set national goals. For instance, subjects, such as life skills and ethics, are ignored simply, because they are not examinable. In the process, they do not teach all the required subjects in order to impart the necessary skills. In this way, they deviate from the national goals to some extent, and this affects their achievement. What they dwell on is transmissive teaching and learning. 
High performing schools attract parents who prefer schools where learners achieve highly, and schools that are ranked among at the top. Enrolling their children in such schools raises their hopes; and they feel lost and disappointed when at the end of the day, their children end up jobless and low spirited.

The graduates, too, feel disillusioned and frustrated. Some end up conducting odd jobs, others join disorderly groups that mislead them. Even for those who have hope of employment, job opportunities have proved to be scarce. Besides, many more youth have ended up with jobs they were not trained in, e.g., graduate teachers, journalists, and lawyers, ending up conducting sales promotions and being paid commission/honorarium, bank clerks, and receptionists. This is clearly a deviation from the proposed. Furthermore, some courses do not deliver on the students' expectations, for instance, International Relations and Diplomacy where the graduate expects to work in a related office, only to end up in sales, and employed to conduct clerical work. This, in turn, has contributed to massive wastage of manpower.

The survey identified the introduction of unexpected challenges with the development in education, such as overcrowded classrooms and higher teacher-pupil ratios; overcrowded classrooms and higher teacher-pupil ratios; weakness in management of teachers with regards to deployment and accountability; inadequate integration of positive values, attitudes, and patriotism in teaching; inadequate general education delivery mechanisms; inadequate inculcation of national values; mismatch between skills acquired and demand of labour market; increase in number of unemployed graduates; increase in white collar crime from graduates of the system; and less faith in the education system by the graduates, parents/guardians, and employers.

Having achieved the MDGs to a large extent, the country should now turn to address the challenges that have emanated in order to sustain the development. The stakeholders who participated in the survey proposed the following measures:

1. Development programmes be organised for teachers;

2. Capacity building programmes be organised for education managers;

3. Use of information and communication technology (ICT) in teaching and learning;

4. Provision of instructional materials to all learners at basic education level;

5. Improving the learning institutions' infrastructure;

6. Strict monitoring and evaluation of curriculum implementation;

7. Review of curriculum to generate skills for work and for life, at every level of education, i.e., primary, secondary, tertiary, and university levels;

8. Integrate other skills to be taught along side mainstream programmes;

9. Introduce talent academies;

10. Conduct regular studies on how to achieve sustained investment and competency in education;

11. Consider evaluating all contents of the curriculum to ensure all areas in the curriculum are taught.

\section{Conclusions and Recommendations}

To conclude, it is evident that education is a mandatory tool in achieving sustainability. Current economic development trends require education in order to sustain them. Education, training, and public awareness are key to moving any society towards sustainability. Today, most learning is informational, which is oriented towards socialization and with little nor no regards towards sustainability. This in turn translates to the managerial view of education. Therefore, asserting ESD within the present educational framework can only meet with limited success. The real need is to change from transmissive learning to transformative learning; 
and this requires a transformed educational paradigm. All information required to be taught in the curriculum should be covered regardless of whether they are examinable or not.

Additionally, the development of education in Kenya has, over time, been measured by the growth in student enrolment and the number of educational institutions. In the process, the vital factor of the quality of the product has been overlooked. The steady growth of student enrolment has not been matched with growth in teaching and learning facilities and resources. The gap in the ratio of teacher to student has continued to widen, reducing the frequencies of contact between the two parties. All these factors combined has affected the quality of producing the educational product (Koteng' \& Dayo, 2012).

ESD is a tool towards achieving sustainability. For example, fire safety education seeks to prevent fires, destruction of property, and loss of lives; and make living more compliant. According to Brundtland (1987, p. 43), sustainable development is development that meets the needs of the present without compromising the ability of future generations to meet their own needs. He elaborated further that sustainable development is envisaged to have three components: environment, society, and economy; the three go hand in hand. For example, a healthy prosperous society relies on a healthy environment, to provide food and resources, safe drinking water, and clean air for its citizens.

Thus, sustainability involves thinking about the future in which environmental, societal, and economic considerations are balanced in pursuit of development and improved quality of life. Adequate implementation of the set national goals of education need to be upheld by the teachers; and evaluation reports ought to be considered during review of the curriculum. The curriculum needs to be designed such that learners acquire sustainable development skills at every level of learning: at primary and secondary school levels, and at university level. In this way, education will truly be aimed at sustainable development since learners will be able to adapt and comply accordingly. In order to entrench itself within sustainable means, implementation of the sustainable development goals (SDGs) below ought to be addressed in the curriculum:

1. SDG No. 4: To ensure inclusive and equitable quality education and promote lifelong learning opportunities for all;

2. SDG No. 9: To build resilient infrastructure, promote inclusive and sustainable industrialization, and foster innovations.

From the fore-going, teaching and learning need not be only transmissive, but practical too since socio-economic development depends on sustainability. Kenya has made good progress towards achieving the development in education. However, the curriculum needs to be implemented such that learners acquire sustainable development skills at every level of learning: primary, secondary schools, and university levels. This will enable learners to adapt and comply accordingly. As advanced by Martin Luther King Jr., the function of education is to teach one to think critically. Intelligence plus character is the goal of true education.

\section{References}

Bossel, H. (1999). Indicators for sustainable development: Theory, method, applications (A report to the Balaton Group, IISD). Brundtland, G. (1987). World commission on environment and development. London: Oxford University Press.

Gagne, R. M., \& Briggs, L. (1979). Principles of instructional design. New York, N.Y.: Holt, Rinehart \& Winston.

Kaimenyi, J. T. (2015). Reforms in the education sector. Public lecture delivered by the Cabinet Secretary, Ministry of Education, Science and Technology, Kenyatta University, Kenya.

Koteng', G. A. (2009). The influence of verbal communication interaction patterns on learners' participation in the classroom in secondary schools in Kisumu Town (Unpublished doctoral dissertation, Moi University, Kenya). 
Koteng', G. A., \& Dayo, C. K. (2012). Challenges faced in producing quality educational products in Kenya. In New horizons in pedagogy (Book chapter). DPCAP, MMUST.

Ministry of Education, Science, and Technology (MOEST). (2003). Syllabus for Kenya certificate of secondary education. Nairobi: Kenya Literature Bureau.

Mwaka, M., Kafwa, V. N., Musamas, J. K., \& Benjamin, K. W. (2013). The national goals of education in Kenya: Interrogating the achievement of national unity. Journal of Education and Unity, 4(4).

Reigelugh, C. M. (1983). Instructional design, theories and models: An overview of their current status. Hillsdale, N.J.: Lawrence Erlbaum Associates.

The Elimu Network. (2007). Kenya national goals of education: Educational training for all. Nairobi.

United Nations. (2012, June 20-22). Poverty reduction, social equity, and environmental protection. Report of The United Nations Conference on Sustainable Development, Rio de Janeiro, Brazil.

Winograd, M., \& Farrow, A. (1995). Sustainable development indicators for decision-making: Concepts, methods, definitions, and use. In Dimensions of sustainable development (Vol. I). EOLSS. 